\title{
Infection of Tilapia tilapinevirus in Mozambique Tilapia (Oreochromis mossambicus), a Globally Vulnerable Fish Species
}

\author{
Pitchaporn Waiyamitra ${ }^{1}$, Chutchai Piewbang ${ }^{2,3}$, Somporn Techangamsuwan ${ }^{2,3}{ }^{\mathbb{C}}$, Woei Chang Liew ${ }^{4,+(\mathbb{C})}$ \\ and Win Surachetpong $1, *$ (D) \\ 1 Department of Veterinary Microbiology and Immunology, Faculty of Veterinary Medicine, Kasetsart \\ University, Bangkok 10900, Thailand; w.doublep@gmail.com \\ 2 Department of Pathology, Faculty of Veterinary Science, Chulalongkorn University, Bangkok 10330, Thailand; \\ alkaline_eart@hotmail.com (C.P.); somporn62@hotmail.com (S.T.) \\ 3 Animal Virome and Diagnostic Development Research Group, Faculty of Veterinary Science, Chulalongkorn \\ University, Bangkok 10330, Thailand \\ 4 Temasek Life Sciences Laboratory, Singapore 117604, Singapore; wcliew@gmail.com \\ * Correspondence: fvetwsp@ku.ac.th \\ † Current address: Aquaculture Department, Singapore Food Agency, Singapore 608550, Singapore.
}

Citation: Waiyamitra, P.; Piewbang, C.; Techangamsuwan, S.; Liew, W.C.; Surachetpong, W. Infection of Tilapia tilapinevirus in Mozambique Tilapia (Oreochromis mossambicus), a Globally Vulnerable Fish Species. Viruses 2021, 13, 1104. https://doi.org/10.3390/ v13061104

Academic Editor: Kyle A. Garver

Received: 22 May 2021

Accepted: 6 June 2021

Published: 9 June 2021

Publisher's Note: MDPI stays neutral with regard to jurisdictional claims in published maps and institutional affiliations.

Copyright: (c) 2021 by the authors. Licensee MDPI, Basel, Switzerland. This article is an open access article distributed under the terms and conditions of the Creative Commons Attribution (CC BY) license (https:// creativecommons.org/licenses/by/ $4.0 /)$.

\begin{abstract}
Tilapia tilapinevirus, or tilapia lake virus (TiLV), is a highly contagious virus found in tilapia and its hybrid species that has been reported worldwide, including in Asia, the Americas, and Africa. In this study, we experimentally challenged Mozambique tilapia (Oreochromis mossambicus) with a virulent TiLV strain, VETKU-TV01, at both low $\left(1 \times 10^{3} \mathrm{TCID}_{50} / \mathrm{mL}\right)$ and high $\left(1 \times 10^{5} \mathrm{TCID}_{50} / \mathrm{mL}\right)$ concentration. After the challenge, the Mozambique tilapia showed pale skin with some hemorrhage and erosion, lethargy, abdominal swelling, congestion around the eye, and exophthalmos; there was a cumulative mortality rate at $48.89 \%$ and $77.78 \%$ in the groups that received the low and high concentration, respectively. Quantitative PCR and in situ hybridization confirmed the presence of TiLV in the internal organs of moribund fish. Notably, severe histopathological changes, including glycogen depletion, syncytial hepatic cells containing multiple nuclei and intracytoplasmic inclusion bodies, and infiltration of melanomacrophage into the spleen, were frequently found in the Mozambique tilapia challenged with high TiLV concentration. Comparatively, the infectivity and pathology of the TiLV infection in Mozambique tilapia and red hybrid tilapia (Oreochromis spp.) were found to be similar. Our results confirmed the susceptibility of Mozambique tilapia, which has recently been determined to be a vulnerable species, to TiLV infection, expanding knowledge that the virus can cause disease in this fish species.
\end{abstract}

Keywords: Tilapia tilapinevirus; TiLV; Mozambique tilapia; infection; pathology

\section{Introduction}

Tilapia Lake Virus Disease (TiLVD) is a new disease caused by Tilapia tilapinevirus, or tilapia lake virus (TiLV), which is a linear, negative-sense single-strand RNA virus containing ten segments; it has a total genome size of 10,323 kb [1,2]. Since 2014, TiLV has been reported on four continents, North America, South America, Asia, and Africa [2-4]. All stages of tilapia, from fry to adult and broodstock, are susceptible to TiLV, with mortality ranging from $5 \%$ to $100 \%$ [2,4-9]. TiLVD has been most extensively reported and studied in several species of tilapia, including Nile tilapia (Oreochromis niloticus) [5,8,10-14], hybrid tilapia (Oreochromis niloticus $\times$ O. aureus) [4], gray tilapia (O. niloticus $\times$ O. aureus) [15], and red hybrid tilapia (Oreochromis sp.) [8,16]. Some other species of fish are also susceptible to TiLV, including giant gourami (Osphronemus goramy), which showed a high mortality rate during laboratory challenge [17]; the virus was also detected in wild river barb (Barbonymus schwanenfeldi) in Malaysia [18]. TiLV primarily affects tilapia and its hybrid species, while most other freshwater fish are resilient to TiLV infection, including snakeskin 
gourami (Trichogaster pectoralis), iridescent shark (Pangasianodon hypophtthalmus), walking catfish (Clarias macrocephalus), striped snake-head fish (Channa striata), climbing perch (Anabas testudineus), common carp (Cyprinus carpio), silver barb (Barbodes gonionotus), Asian sea bass (Lates calcarifer) [17], and Indian major carp (Labeo rohita) [19].

Tilapias of the genus Oreochromis are a popular species for aquaculture in several regions of the world; three of the most common species are Nile tilapia (Oreochromis niloticus), blue tilapia (Oreochromis aureus), and Mozambique tilapia (Oreochromis mossambicus) [20-24]. Mozambique tilapia is known to grow more slowly, mature at a young age, and be more tolerant to wide salinity fluctuations than Nile tilapia [21-25]. Therefore, Mozambique tilapia has been used in breeding to improve the saltwater and cold tolerance of other tilapias $[21,26,27]$. The species has also been used as a model to study environmental factors [28,29] and response to pathogens [30]. Mozambique tilapia is native to the river of South Africa [31], but its numbers have decreased due to introduction of invasive fish species, including Nile tilapia. This invasion has resulted in the extirpation of Mozambique tilapia due to habitat competition and hybridization [32-37]. The Mozambique tilapia is now therefore considered a globally vulnerable species and is on the International Union for Conservation in Nature (IUCN) Red List [38]. In addition to habitat competition, pathogen carrying and spill over between native and invasive fish species will result in decreasing numbers of the native species. The susceptibility of Mozambique tilapia to pathogens that lead to massive decreases in number is therefore essential to investigate.

Although there is no direct experimental study on the susceptibility of Mozambique tilapia to TiLV, one previous study suggested that TiLV can replicate and infect their cells [39]. Furthermore, the natural infection of red hybrid tilapia with a Mozambique tilapia genetic background with TiLV (O. niloticus $\times$ O. mossambicus) has previously been reported [40]. Given the genetic similarities between Nile tilapia and Mozambique tilapia, there is a significant possibility that TiLV may cause infection in this species.

This study aimed to investigate the susceptibility of Mozambique tilapia (O. mossambicus) to TiLV infection by comparing TiLV infection in red hybrid and Mozambique tilapia, as well as comparing the infectivity and biology of the infection in Mozambique tilapia after exposure to both low and high concentrations of TiLV. It was determined that, regardless of the challenge dose, TiLV can cause clinical signs and mortality in Mozambique tilapia, though to different degrees of virus replication and severity.

\section{Materials and Methods}

\subsection{Animals, Virus and Ethical Statement}

Four hundred Mozambique tilapia (Oreochromis mossambicus) (average weight $15 \mathrm{~g} \pm 0.5 \mathrm{~g}$ ) were obtained from Temasek Life Sciences Laboratory, Singapore. The fish had no previous history of TiLV infection and were in good health post transportation to Thailand. Seventy red hybrid tilapias (average weight $10 \mathrm{~g} \pm 0.5 \mathrm{~g}$ ) were acquired from a tilapia hatchery with no history of TiLV infection from Saraburi province, Thailand. Both Mozambique tilapia and red hybrid tilapia were acclimatized at $28^{\circ} \mathrm{C}$ in $400 \mathrm{~L}$ aquarium tank for seven days with daily water exchange at $50 \%$. The water qualities were monitored every two days in terms of temperature $\left(28-29^{\circ} \mathrm{C}\right), \mathrm{pH}(7.6-8.2)$, ammonia $(0.2-0.5 \mathrm{ppm})$, and nitrite $(0-0.03 \mathrm{ppm})$. Fish were fed with a commercial tilapia diet at the rate of $3 \%$ of total body weight per day. Before the experiment, five Mozambique tilapia and five red hybrid tilapia fish were randomly collected to screen for external parasites via skin scraping, gills biopsy, and bacterial colony count using tryptic soy agar. As previously described, a pool of spleen from five fish was processed for RNA extraction and TiLV screening by reverse transcription quantitative polymerase chain reaction (RT-qPCR) [41]. The animal use protocol was approved by the Institutional Animal Care and Use Committee of Kasetsart University, Bangkok, Thailand, under the protocol number ACKU61-VET-013. TiLV strain VETKU-TV01 was isolated in 2016 from red hybrid tilapia in a tilapia farm, Pathum Thani province, Thailand [42]. The virus was propagated in E-11 cells, a clone of SSN-1 cells [43]. The amount of TiLV (TCID 50 ) was determined using Reed and Muench method [44]. 


\subsection{Challenge Study}

Three hundred and sixty Mozambique tilapia (weight $15 \pm 0.5 \mathrm{~g}$ ) were separated into three groups (four replicates/group) in a total of 12 tanks, with 30 fish/tank. Three tanks were used to record mortality and monitor morbidity and the fourth was used for sample collection. The details of each group are as follows: (1) control group; fish were intraperitoneally (IP) injected with uninfected E-11 cells and L-15 medium at $50 \mu \mathrm{L} /$ fish; (2) low TiLV concentration; fish were IP-injected with TiLV at $1 \times 10^{3} \mathrm{TCID}_{50} / \mathrm{mL}, 50 \mu \mathrm{L} /$ fish; (3) high TiLV concentration; fish were IP-injected with TiLV at $1 \times 10^{5} \mathrm{TCID}_{50} / \mathrm{mL}, 50 \mu \mathrm{L} / \mathrm{fish}$. The sixty red hybrid tilapia were equally divided into two tanks, a sampling tank and a mortality recording tank. All red hybrid tilapia were IP-injected with high TiLV concentration at $1 \times 10^{5} \mathrm{TCID}_{50} / \mathrm{mL}, 50 \mu \mathrm{L} /$ fish. At $0,3,6$, and 12 days post-challenge (dpc), five fish were randomly collected from a sampling tank and processed for RT-qPCR and histopathology. Five red hybrid tilapia (control fish) were IP-injected with uninfected E-11 cells and L-15 medium at $50 \mu \mathrm{L} /$ fish. All fish were euthanized by an overdose of eugenol (Aquanes ${ }^{\circledR}$; Better Pharma; Bangkok, Thailand). The spleens were collected and stored at $-20{ }^{\circ} \mathrm{C}$ until processed.

\subsection{RNA Extraction and cDNA Synthesis}

Total RNA was extracted from the spleens (approximately $30 \mathrm{mg}$ of tissue) of both the Mozambique and red hybrid tilapia at the defined experimental time points using $1 \mathrm{~mL}$ of TRIzol ${ }^{\circledR}$ reagent (Invitrogen, Carlsbad, CA, USA) according to the manufacturer's instructions. Total RNA concentration and quality were estimated using spectrophotometry (NanoDrop $^{\mathrm{TM}}$ 2000; Thermo Fisher Scientific Inc.; Waltham, MA, USA). For cDNA synthesis, $1 \mu \mathrm{g}$ of total RNA was converted to cDNA using ReverTraAce ${ }^{\circledR}$ qPCR RT kit (TOYOBO CO., LTD., Osaka, Japan) according to the manufacturer's protocol. The cDNA templates were stored at $-80^{\circ} \mathrm{C}$ until analysis.

\subsection{Quantitative Polymerase Chain Reaction ( $q P C R$ )}

The qPCR was analyzed in a CFX96 real-time PCR thermocycler (Bio-Rad, Hercules, CA, USA) using an SYBR-based qPCR assay [41]. Briefly, the reaction consisted of $5 \mu \mathrm{L}$ of $2 \times \mathrm{iTaq}^{\mathrm{TM}}$ universal SYBR Supermix (Bio-Rad, Hercules, CA, USA), the $0.3 \mu \mathrm{L}$ forward primer was TiLV-112F 5'-CTGAGCTAAAGAGGCAATATGGATT- $3^{\prime}$, and the $0.3 \mu$ L reverse primer was TiLV-112-R 5'-CGTGCGTACTCGTTCAGTATAAGTTCT-3' 200 ng of cDNA template and molecular water to an absolute volume of $10 \mu \mathrm{L}$. The cycling condition was as follows: $95^{\circ} \mathrm{C}$ for $3 \mathrm{~min}, 40$ cycles of denaturing at $95^{\circ} \mathrm{C}$ for $10 \mathrm{~s}$, annealing and extension at $60{ }^{\circ} \mathrm{C}$ for $30 \mathrm{~s}$. At the end of the qPCR reaction, melting curve analysis was carried out at $65{ }^{\circ} \mathrm{C}$ to $95{ }^{\circ} \mathrm{C}$ with $0.5^{\circ} \mathrm{C}$ per $5 \mathrm{~s}$ increment. The calculation of the amount of TiLV genomic RNA in the spleen tissue was performed by SYBR-based qPCR assay as previously described [41]. The amount of TiLV genomic RNA was extrapolated from Ct value of each sample by comparing it to the standard curve of ten-fold serial dilutions of plasmid containing TiLV segment 3, as previously described [45].

\subsection{Histopathology}

The liver and spleen samples from the control and challenge groups were fixed in $10 \%$ $(v / v)$ formalin for $24 \mathrm{~h}$ and then transferred into $70 \%$ ethanol solution. The samples were embedded in paraffin wax, sectioned, and stained with Hematoxylin and Eosin (H\&E). The slides were scanned using VS120 ${ }^{\circledR}$ Virtual Microscopy Slide Scanning (Olympus, Tokyo, Japan) and examined under an Olympus OlyVIA Ver.3.1 program (Olympus, Tokyo, Japan).

\subsection{In Situ Hybridization}

The in situ hybridization (ISH) protocol was performed in $4 \mu \mathrm{m}$ thick formalin-fixed paraffin-embedded (FFPE) slides according to the previously described protocol [46]. Briefly, the TiLV probe covering $491 \mathrm{bp}$ of segment 3 of TiLV was amplified using the digoxigenin (DIG)-labeled oligonucleotides and prepared using a PCR DIG Probe Syn- 
thesis Kit (Roche Diagnostics, Basel, Switzerland). The FFPE slides were deparaffinized, rehydrated, and then rinsed in phosphate-buffered saline (PBS) pH 7.4. Subsequently, the slides were digested with Proteinase K, post-fixation, acetylation, and pre-hybridization, then hybridized with the $20 \mathrm{ng} / \mu \mathrm{L}$ specific probes at $42{ }^{\circ} \mathrm{C}$ overnight. Thereafter, the DIG-labelled signals were visualized using $100 \mu \mathrm{L}$ of anti-DIG-alkaline phosphatase Fab fragments antibody (Roche, Basel, Switzerland) (1:200 in 1× blocking solution) in a combination of the StayGreen/AP Plus (Abcam, Cambridge, MA, USA). The slides were then counterstained with Nuclear Fast Red. Sections were considered positive for TiLV infection if green precipitates in the association of cellular morphology were visualized. Non-specific staining was assessed using an irrelevant canine bocavirus-2 (CBoV-2) probe [47].

\section{Results}

\subsection{Susceptibility of Mozambique Tilapia to Tilapia Lake Virus}

At $28 \mathrm{dpc}$, the cumulative mortality in Mozambique tilapia with low $\left(1 \times 10^{3} \mathrm{TCID}_{50} / \mathrm{mL}\right)$ and high $\left(1 \times 10^{5} \mathrm{TCID}_{50} / \mathrm{mL}\right)$ concentration of $\mathrm{TiLV}$ was $48.89 \%$ and $77.78 \%$, respectively (Figure 1). At $4 \mathrm{dpc}$, moribund Mozambique tilapia developed clinical signs of TiLV infection, including skin hemorrhage, lethargy, pale skin, abdominal swelling, skin erosion, congestion around the eye, and exophthalmos (Figure 2). Notably, mortality in fish exposed to high TiLV concentration began at $4 \mathrm{dpc}$, while the mortality in fish exposed to low TiLV concentration did not start until $7 \mathrm{dpc}$. Mortality in both low TiLV and high TiLV-exposed fish ended at $19 \mathrm{dpc}$ (Figure 1). Intraperitoneal challenges (IP) of red hybrid tilapia with TiLV at $1 \times 10^{5} \mathrm{TCID}_{50} / \mathrm{mL}$ were conducted to compare clinical signs, pathology, and mortality patterns. Similar to the Mozambique tilapia, the red hybrid tilapia also showed skin hemorrhage, swimming at the bottom of the tank, skin and fin erosion, exophthalmos, and scale protrusion, with the first mortality at $6 \mathrm{dpc}$. At the end of the experiment, the cumulative mortality of the red hybrid tilapia was $66.67 \%$ (Figure 1 ). No clinical signs and mortality developed in the control Mozambique and red hybrid tilapia.

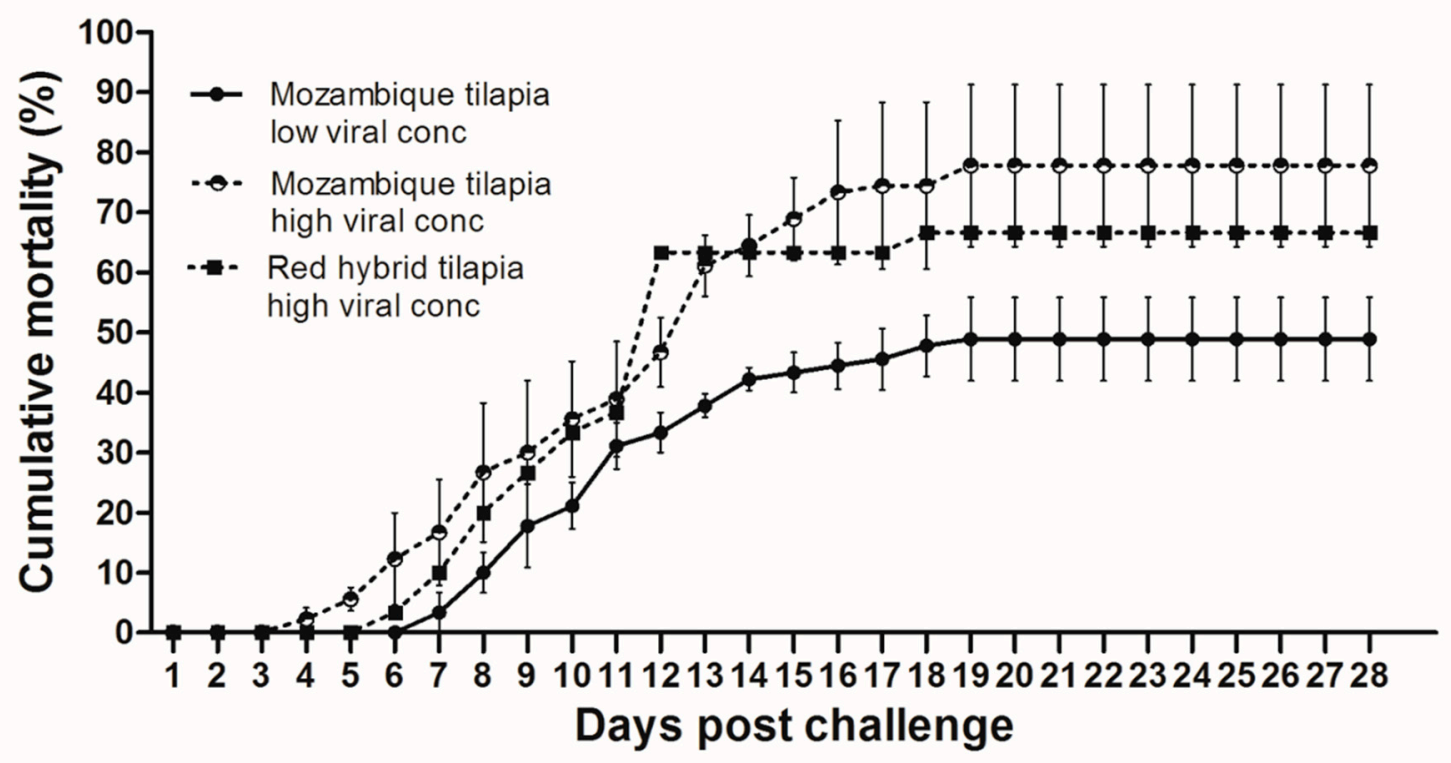

Figure 1. Cumulative mortality after Tilapia lake virus (TiLV) infection in Mozambique tilapia (Oreochromis mossambicus) and red hybrid tilapia (Oreochromis spp.). Fish were intraperitoneally challenged with TiLV at low viral concentration $\left(1 \times 10^{3} \mathrm{TCID}_{50} / \mathrm{mL}\right)$ and high viral concentration $\left(1 \times 10^{5} \mathrm{TCID}_{50} / \mathrm{mL}\right)$ per fish. Graph represents mortality in each group with triplicates, 30 fish per tank (a total of 90 fish/group). Mortality was recorded for 28 days. 


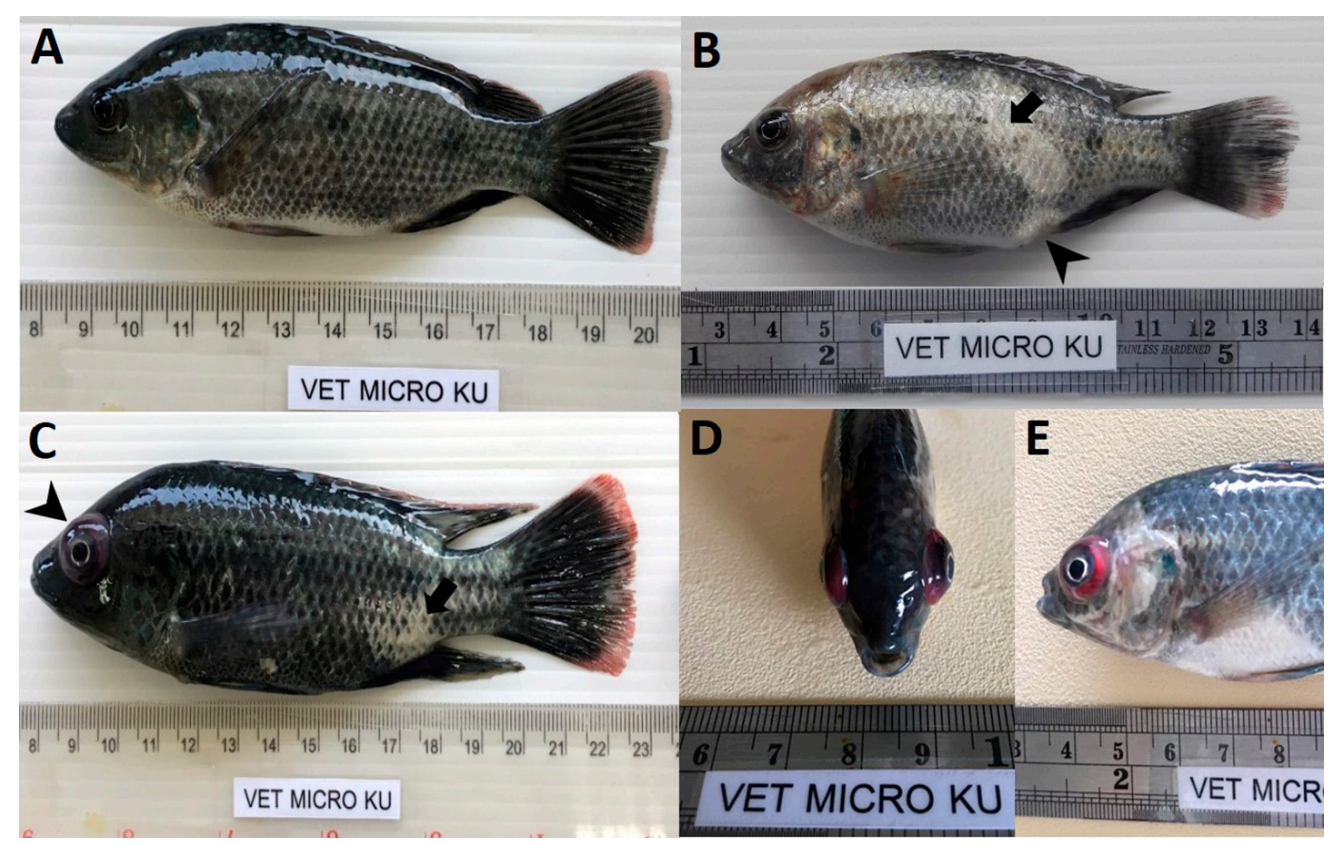

Figure 2. Clinical signs of TiLV infection in Mozambique tilapia (Oreochromis mossambicus). (A) Control uninfected fish. (B) Fish infected with TiLV at low viral concentration $\left(1 \times 10^{3} \mathrm{TCID}_{50} / \mathrm{mL}\right)$, skin erosion (arrow) and abdominal swelling (arrowhead). (C) Fish infected with TiLV at high viral concentration $\left(1 \times 10^{5} \mathrm{TCID}_{50} / \mathrm{mL}\right)$, skin erosion (arrow) and exophthalmos (arrowhead). (D,E) Fish infected with TiLV at high viral concentration $\left(1 \times 10^{5} \mathrm{TCID}_{50} / \mathrm{mL}\right)$, exophthalmos and congestion of the eye.

\subsection{Confirmation of TiLV Infection in Moribund Mozambique Tilapia}

To further confirm the susceptibility of Mozambique tilapia to TiLV, spleens were collected from low and high TiLV-challenged fish at 3, 6, and $12 \mathrm{dpc}$. As shown in Table 1, TiLV was detected in 3 out of 5 fish (60\%) and 4 out of 5 fish (80\%) exposed to the low concentration of TiLV at 3 and $6 \mathrm{dpc}$, respectively, with the virus concentration ranging from $9.7 \times 10-4.8 \times 10^{5}$ copies per $\mu \mathrm{g}$ of total RNA. No TiLV was detected in the fish exposed to the low concentration at $12 \mathrm{dpc}$. Conversely, all of the fish exposed to high concentration of TiLV had TiLV in their spleen as early as $3 \mathrm{dpc}\left(1.1 \times 10^{4}-3.5 \times 10^{4}\right.$ copies per $\mu g$ of total RNA), which remained detectable in all fish until $12 \mathrm{dpc}\left(3.3 \times 10^{5}-2.3 \times 10^{6}\right.$ copies per $\mu \mathrm{g}$ of total RNA). Throughout the studied period, no TiLV was detected in the unchallenged fish.

Table 1. Persistence of TiLV genomic RNA in spleen of challenged Mozambique tilapia.

\begin{tabular}{|c|c|c|c|}
\hline \multicolumn{4}{|c|}{$\begin{array}{c}\text { Positive Samples/Total Sample } \\
\text { (Number of Viral Copies/ } \mu \text { g of Total RNA) }\end{array}$} \\
\hline Day Post Challenge (DPC) & Control & $\begin{array}{c}\text { Low TiLV Conc. } \\
\left(1 \times 10^{3} \mathrm{TCID}_{50} / \mathrm{mL}\right)\end{array}$ & $\begin{array}{c}\text { High TiLV Conc. } \\
\left(1 \times 10^{5} \mathrm{TCID}_{50} / \mathrm{mL}\right)\end{array}$ \\
\hline 3 & $0 / 5$ & $\begin{array}{c}3 / 5 \\
\left(9.7 \times 10^{-1} \times 10^{3}\right)\end{array}$ & $\begin{array}{c}5 / 5 \\
\left(1.1 \times 10^{4}-3.5 \times 10^{4}\right)\end{array}$ \\
\hline 6 & $0 / 5$ & $\begin{array}{c}4 / 5 \\
\left(1.3 \times 10^{3}-4.8 \times 10^{5}\right)\end{array}$ & $\begin{array}{c}5 / 5 \\
\left(2.7 \times 10^{2}-2.6 \times 10^{6}\right)\end{array}$ \\
\hline 12 & $0 / 5$ & $0 / 5$ & $\begin{array}{c}5 / 5 \\
\left(3.3 \times 10^{5}-2.3 \times 10^{6}\right)\end{array}$ \\
\hline
\end{tabular}

\subsection{Histopathological Finding and In Situ Hybridization in the Challenge Fish}

Normal hepatocytes with adequate glycogen storage were found in the liver of control fish (Figure 3A,C). No extensive histopathological changes were found in the livers and 
spleens of Mozambique tilapia that were challenged by the low concentration of TiLV (Figure 3C,D). However, severe histopathological changes could be found in red hybrid tilapia and Mozambique tilapia exposed to high concentration of TiLV at $6 \mathrm{dpc}$. Depletion of glycogen storage, loss of sinusoid structure, presence of syncytial giant cells containing multiple nuclei, and intracytoplasmic inclusion bodies were observed in the livers of both species (Figure 3A,E). A few melanomacrophage centers (MMCs) and normal lymphocytes surrounded by a sheath of reticular cells were observed in the spleen of the control red hybrid and Mozambique tilapia (Figure 3B,D), while an abundance of MMCs and depletion of red blood cells were observed in the spleens of the fish exposed to the high TiLV concentration (Figure 3B,F). No remarkable change was observed in the gills or intestines of the challenged fish. The localization of TiLV RNA in infected tissues including liver, intestines, heart, and gills was further confirmed by ISH. Intriguingly, positive signals with green coloration were clearly observed in all tested Mozambique tilapia tissues exposed to the high TiLV concentration, while positive signals were noted to a lesser extent in liver and intestines of Mozambique tilapia exposed to the low TiLV concentration. Conversely, no positive hybridization signal was detected in either the infected tissues exposed to a non-irrelevant probe or the uninfected control tissue samples (Figure 4).

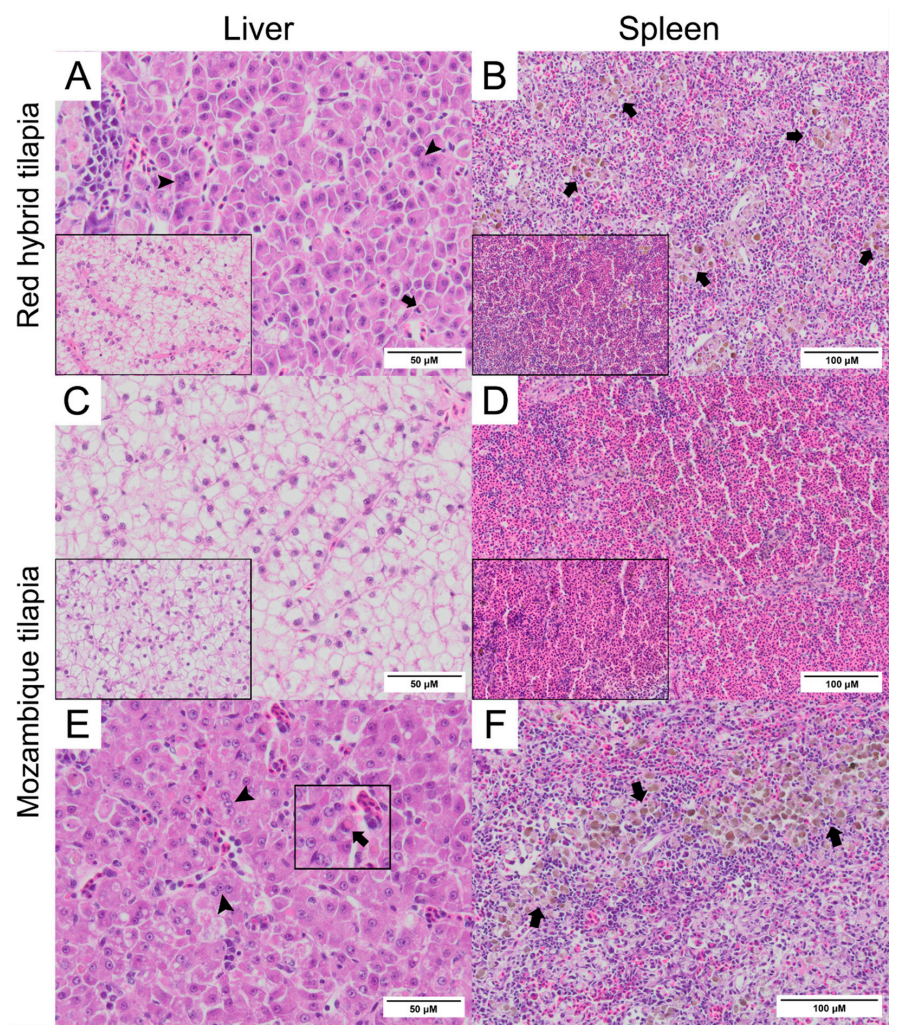

Figure 3. Histopathology of liver and spleen of red hybrid tilapia (Oreochromis spp.) and Mozambique tilapia (Oreochromis mossambicus) after 6 days post TiLV challenged. (A) Liver of red hybrid tilapia challenged with high TiLV concentration; depletion of glycogen, syncytial cells formation (arrowheads) and intracytoplasmic inclusion bodies (arrows), normal liver (inlet). (B) Spleen of red hybrid tilapia challenged with high TiLV showed depletion of red blood cells and increased melanomacrophage centers (MMCs) (arrows), normal spleen of red hybrid tilapia (inlet). (C) Liver of Mozambique tilapia challenged with low TiLV concentration, normal liver of Mozambique tilapia (inlet). (D) Spleen of Mozambique tilapia challenged with low TiLV concentration, normal spleen of Mozambique tilapia (inlet). (E) Liver of Mozambique tilapia challenged with high TiLV concentration; glycogen depletion, syncytial giant cells contained multiple nuclei (arrowheads) and intracytoplasmic inclusion bodies (inlet, arrows). (F) Spleen of Mozambique tilapia challenged with high TiLV concentration, infiltration of MMCs (arrows). 


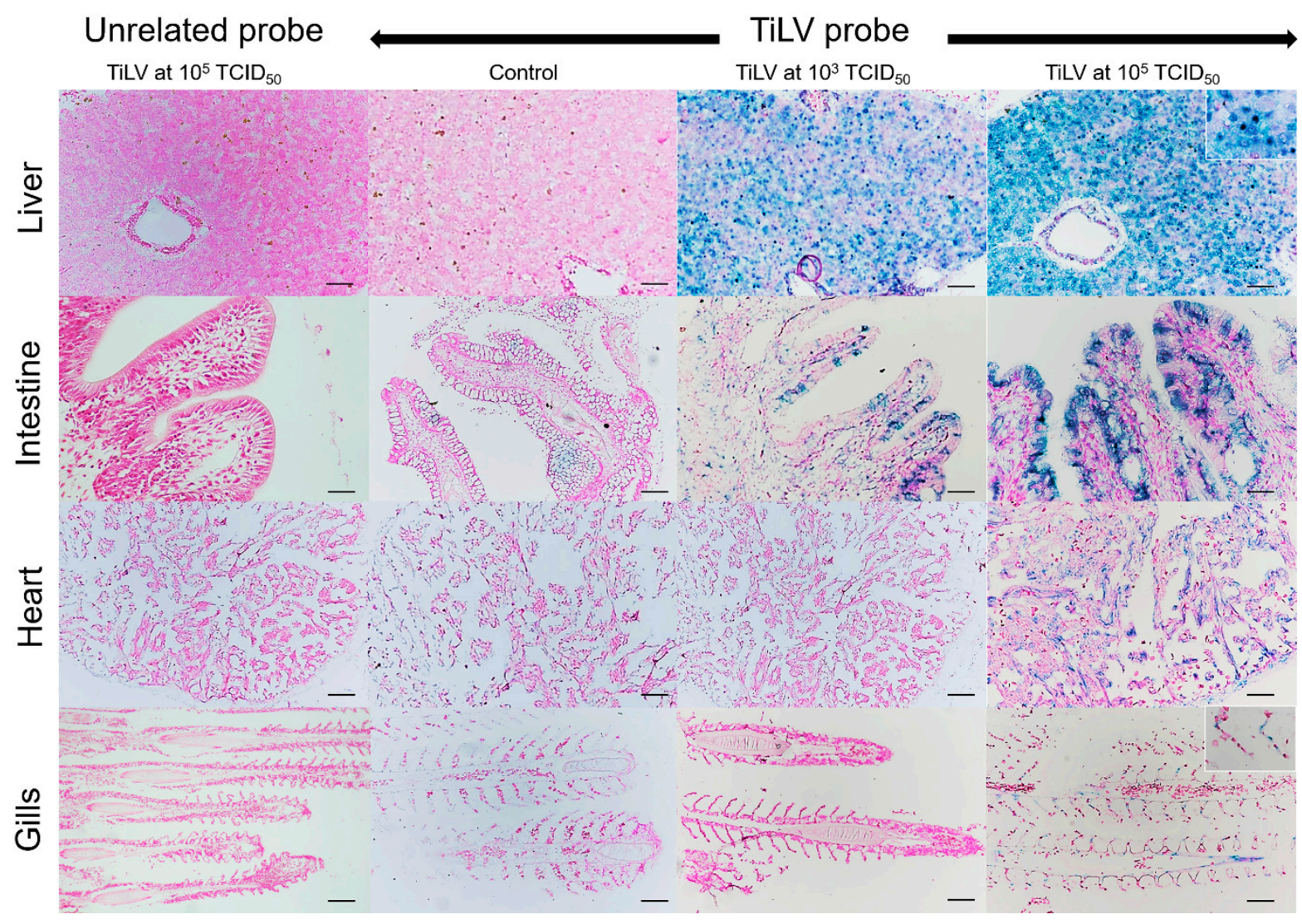

Figure 4. In situ hybridization (ISH) of TiLV RNA detection in Mozambique tilapia inoculation of TiLV at $1 \times 10^{3} \mathrm{TCID}_{50} / \mathrm{mL}$ and $1 \times 10^{5} \mathrm{TCID}_{50} / \mathrm{mL}$ concentrations. The TiLV RNA was detected in liver and intestinal epithelium of TiLV-infected Mozambique tilapia in both inoculation concentrations. The TiLV RNA labelling was evidence in the nucleus of hepatocytes (above inset), intestinal epithelium, myocardium, and gills epithelium (lower inset) of experimental Mozambique tilapia inoculation with TiLV at $1 \times 10^{5} \mathrm{TCID}_{50} / \mathrm{mL}$ concentration. No evidence of hybridization signal was observed in the control fish and in the TiLV-infected Mozambique tilapia sections inoculation with CBoV-2 probe (unrelated probe). Bars indicate $120 \mu \mathrm{m}$.

\section{Discussions}

Tilapia tilapinevirus, aka tilapia lake virus (TiLV), was first described in farmed and wild tilapia in Israel [4] and later reported in sixteen additional countries [2,48,49]. Although the potency of TiLV has been demonstrated in various species of tilapia including Nile tilapia (Oreochromis niloticus), blue tilapia (O. aureus), and its hybrid species [4,5,15,42,50,51], there have been no reports of TiLV infection in Mozambique tilapia, which is genetically close to the Nile tilapia, a susceptible host to TiLV infection. This study showed that Mozambique tilapia (O. mossambicus) is also susceptible to TiLV infection. Generally, high morbidity and mortality occurred within ten days post challenge. Moribund fish showed pale skin with occasional hemorrhage and erosion, lethargy, abdominal swelling, congestion around the eye, and exophthalmos. Notably, the cumulative mortality in the groups that received low and high TiLV concentration was $48.89 \%$ and $77.78 \%$, respectively. This high mortality in Mozambique tilapia is similar to previous reports in red hybrid (Oreochromis spp.) and Nile tilapia (O. niloticus), with cumulative mortality in these species ranging from $63-86 \%$ [17,42]. Mugimba et al. (2019) [15] reported $80-100 \%$ mortality in gray tilapia (O. niloticus $\times$ O. aureus) and red tilapia (Oreochromis spp.) after experimental challenge by TiLV.

Although the IP challenge did not mimic the natural route of virus infection as compared to the cohabitation challenge model, it provides more benefits, including an equal challenge dose in each individual fish. It also makes it more practical to compare changes in genes in the population, and most of the laboratory-based infection experiments rely 
on the IP injection of the virus infection [4,15,42,52]. Certainly, the strain of the virus, challenge dose, and species of tilapia could affect the infection's outcome and lead to different mortality rates in these studies. The clinical signs in the observed Mozambique and red hybrid tilapia were quite similar to the clinical signs reported in other tilapias $[5,12,42,50,53]$. Additionally, the histopathological changes in TiLV-infected Mozambique tilapia include syncytial cell formation and degeneration of hepatocytes, depletion of red blood cells and increased MMCs in the spleen. Expectedly, infection with high TiLV concentration induces severe histopathological changes and the presence of positive signal in different organs of the fish. Notably, distinct histopathological changes, including glycogen depletion, syncytial giant cells contained multiple nuclei, and intracytoplasmic inclusion bodies were found in the liver; depletion of red blood cells and increased MMCs in the spleen of Mozambique tilapia and red hybrid tilapia received high TiLV concentration. Comparatively, these pathological changes were reported in different species of fish under natural and experimental challenge by TiLV $[42,46,54,55]$.

Previously, TiLV-genomic RNA was detected in the intestine of Nile tilapia as early as $24 \mathrm{~h}$ after intragastric challenge [54]. The results of this study revealed a positive hybridization of TiLV in multiple organs, including the intestine, gills, heart, and liver, of TiLV-challenged Mozambique tilapia tissues. Interestingly, a negative ISH was found in heart and gills of the Mozambique tilapia that received the low TiLV concentration. Such distinct ISH reaction in organs based on the TiLV concentration given to the fish suggests virus tropisms in the tissues of the fish. A previous study found that many types of tilapia tissue, such as the gills, brain, liver, and head kidneys, showed positive signals of ISH reaction [10,17]. As expected, high TiLV challenge led to severe histopathological alterations, which is in accordance with the presence of high TiLV RNA in tissues. This is the first study to report the susceptibility of Mozambique tilapia to TiLV; it is important to note that both red hybrid and Mozambique tilapia show similar patterns of morbidity and mortality after TiLV infection in that mortality begins at 4-6 days post challenge. Based on phylogenetic analysis and sequence comparisons among tilapia species, it has been suggested that these species have a close genetic background with possible similar target cells, receptors, or details to support TiLV replication [56-58]. Moreover, the presence of TiLV-genomic RNA was detected in the spleen of the Mozambique tilapia, confirming its susceptibility to TiLV. Indeed, TiLV persists in fish challenged with high TiLV concentration until $12 \mathrm{dpc}$, while no virus was detected in fish inoculated with low TiLV concentration at $12 \mathrm{dpc}$, suggesting that the immune system may contribute to the clearance of the virus at low concentration prior to establishment of effective infection. Given the detection of TiLV at 3 and $6 \mathrm{dpc}$ in the low TiLV fish, we believe that the virus was successful in establishing the infection, but that the infectivity may not be efficient enough to overcome the immune response of the fish. A significant expression of immune-related genes including $\mathrm{Mx}$ was reported in zebrafish upon TiLV challenge [52]. Thus, the activation of an antiviral response occurs during early infection and could provide immediate protection. Previous studies demonstrated that Mozambique tilapia is susceptible to many pathogens, including virus [59] and bacteria $[60,61]$. Our study extends the current knowledge by showing that TiLV, one of the important emerging diseases in tilapia, can cause disease in the species. As the Mozambique tilapia is now on the IUCN Red List due to habitat competition from Nile tilapia, prevention of a common tilapia pathogen like the TiLV infection in natural Mozambique tilapia is necessary for the conservation of this species.

In conclusion, our results demonstrated that Mozambique tilapia is susceptible to TiLV infection. It remains unknown whether any underlying factors could contribute to difference in susceptibility of TiLV in different tilapia strains. Nonetheless, the study confirmed that TiLV can cause TiLVD in the Mozambique tilapia, with clinical signs and pathology similar to those found in the Nile and red hybrid tilapia. This information could be considered in aquaculture practice, as many fish species share water resources and are commonly cultured in the polyculture system. As such, avoiding the introduction of 
susceptible fish species and the implementation of appropriate controls will reduce the risk of introducing TiLV to both farms and nature.

Author Contributions: Conceptualization, W.C.L. and W.S.; methodology, P.W., C.P., S.T. and W.S.; validation, C.P., S.T. and W.S.; investigation, P.W., C.P., S.T. and W.S.; resources, W.C.L. and W.S.; data curation, P.W., C.P., S.T. and W.S.; writing-original draft preparation, P.W., C.P. and W.S.; writingreview and editing, P.W., C.P., S.T., W.C.L. and W.S.; visualization, P.W. and W.S.; supervision, S.T. and W.S.; project administration, W.S.; funding acquisition, W.S. All authors have read and agreed to the published version of the manuscript.

Funding: This research was supported by Kasetsart University Research and Development Institute under the project number FF (KU) 25.64. This project was funded by the Faculty of Veterinary Medicine, Kasetsart University, Bangkok, Thailand and Innovation Support Fund from Temasek Life Sciences Laboratory, Singapore. C.P. was supported by the Ratchadapisek Somphot Fund for Postdoctoral Fellowship, Chulalongkorn University.

Institutional Review Board Statement: The study was conducted according to the guidelines of the Declaration of Helsinki, and approved by the Institutional Animal Care and Use Committee of Kasetsart University, Bangkok, Thailand, under the protocol number ACKU61-VET-013 approved on 2 April 2018.

Informed Consent Statement: Not Applicable.

Data Availability Statement: The data presented in this study are available on request from the corresponding author.

Acknowledgments: We would like to thank Lydia Tan Shun En for her valuable help.

Conflicts of Interest: The authors declare no conflict of interest.

\section{References}

1. Bacharach, E.; Mishra, N.; Briese, T.; Zody, M.C.; Kembou Tsofack, J.E.; Zamostiano, R.; Berkowitz, A.; Ng, J.; Nitido, A.; Corvelo, A.; et al. Characterization of a Novel Orthomyxo-like Virus Causing Mass Die-Offs of Tilapia. MBio 2016, 7, e00431-16. [CrossRef]

2. Surachetpong, W.; Roy, S.R.K.; Nicholson, P. Tilapia lake virus: The story so far. J. Fish Dis. 2020, 43, 1115-1132. [CrossRef]

3. Ahasan, M.S.; Keleher, W.; Giray, C.; Perry, B.; Surachetpong, W.; Nicholson, P.; Al-Hussinee, L.; Subramaniam, K.; Waltzak, T.B. Genomic Characterization of Tilapia Lake Virus Isolates Recovered from Moribund Nile Tilapia (Oreochromis niloticus) on a Farm in the United States. Microbiol. Resour. Announc. 2020, 9, e01368-19. [CrossRef] [PubMed]

4. Eyngor, M.; Zamostiano, R.; Kembou Tsofack, J.E.; Berkowitz, A.; Bercovier, H.; Tinman, S.; Lev, M.; Hurvitz, A.; Galeotti, M.; Bacharach, E.; et al. Identification of a novel RNA virus lethal to tilapia. J. Clin. Microbiol. 2014, 52, 4137-4146. [CrossRef]

5. Behera, B.K.; Pradhan, P.K.; Swaminathan, T.R.; Sood, N.; Paria, P.; Das, A.; Verma, D.K.; Kumar, R.; Yadav, M.K.; Dev, A.K.; et al. Emergence of Tilapia Lake Virus associated with mortalities of farmed Nile Tilapia Oreochromis niloticus (Linnaeus 1758) in India. Aquaculture 2018, 484, 168-174. [CrossRef]

6. Dong, H.T.; Senapin, S.; Gangnonngiw, W.; Nguyen, V.V.; Rodkhum, C.; Debnath, P.P.; Delamare-Deboutteville, J.; Mohan, C.V. Experimental infection reveals transmission of tilapia lake virus (TiLV) from tilapia broodstock to their reproductive organs and fertilized eggs. Aquaculture 2020, 515, 734541. [CrossRef]

7. Nicholson, P.; Fathi, M.A.; Fischer, A.; Mohan, C.; Schieck, E.; Mishra, N.; Heinimann, A.; Frey, J.; Wieland, B.; Jores, J. Detection of Tilapia Lake Virus in Egyptian fish farms experiencing high mortalities in 2015. J. Fish Dis. 2017, 40, 1925-1928. [CrossRef] [PubMed]

8. Surachetpong, W.; Janetanakit, T.; Nonthabenjawan, N.; Tattiyapong, P.; Sirikanchana, K.; Amonsin, A. Outbreaks of Tilapia Lake Virus Infection, Thailand, 2015-2016. Emerg. Infect. Dis. 2017, 23, 1031-1033. [CrossRef] [PubMed]

9. Yamkasem, J.; Tattiyapong, P.; Kamlangdee, A.; Surachetpong, W. Evidence of potential vertical transmission of tilapia lake virus. J. Fish. Dis. 2019, 42, 1293-1300. [CrossRef]

10. Dong, H.; Siriroob, S.; Meemetta, W.; Sanimanawong, W.; Gangnonngiw, W.; Pirarat, N.; Khunrae, P.; Rattanarojpong, T.; Vanichviriyakit, R.; Senapin, S. Emergence of tilapia lake virus in Thailand and an alternative semi-nested RT-PCR for detection. Aquaculture 2017, 476, 111-118. [CrossRef]

11. Fathi, M.; Dickson, C.; Dickson, M.; Leschen, W.; Baily, J.; Muir, F.; Ulrich, K.; Weidmann, M. Identification of Tilapia Lake Virus in Egypt in Nile tilapia affected by 'summer mortality' syndrome. Aquaculture 2017, 473, 430-432. [CrossRef]

12. Ferguson, H.W.; Kabuusu, R.; Beltran, S.; Reyes, E.; Lince, L.A.; Del-Pozo, J. Syncytial hepatitis of farmed tilapia, Oreochromis niloticus (L.): A case report. J. Fish Dis. 2014, 37, 583-589. [CrossRef]

13. Koesharyani, I.; Gardenia, L.; Widowati, Z.; Khumaria, K.; Rustianti, D. Studi kasus infeksi tilapia lake virus (TiLV) pada ikan nila (Oreochromis niloticus). J. Ris. Akuakultur. 2018, 13, 85-92. [CrossRef] 
14. Mugimba, K.K.; Chengula, A.A.; Wamala, S.; Mwega, E.D.; Kasanga, C.J.; Byarugaba, D.K.; Mdegela, R.H.; Tal, S.; Bornstein, B.; Dishon, A.; et al. Detection of tilapia lake virus (TiLV) infection by PCR in farmed and wild Nile tilapia (Oreochromis niloticus) from Lake Victoria. J. Fish. Dis. 2018, 41, 1181-1189. [CrossRef]

15. Mugimba, K.K.; Tal, S.; Dubey, S.; Mutoloki, S.; Dishon, A.; Evensen, Ø.; Munang'andu, H.M. Gray (Oreochromis niloticus x O. aureus) and Red (Oreochromis spp.) tilapia show equal susceptibility and proinflammatory cytokine responses to experimental Tilapia Lake Virus infection. Viruses 2019, 11, 893.

16. Yamkasem, J.; Tattiyapong, P.; Gorgoglione, B.; Surachetpong, W. Uncovering the first occurrence of Tilapia parvovirus in Thailand in tilapia during co-infection with Tilapia tilapinevirus. Transbound. Emerg. Dis. 2021, in press. [CrossRef]

17. Jaemwimol, P.; Rawiwan, P.; Tattiyapong, P.; Saengnual, P.; Kamlangdee, A.; Surachetpong, W. Susceptibility of important warm water fish species to tilapia lake virus (TiLV) infection. Aquaculture 2018, 497, 462-468. [CrossRef]

18. Abdullah, A.; Ramly, R.; Ridzwan, M.S.M.; Sudirwan, F.; Abas, A.; Ahmad, K.; Murni, M.; Kua, B.C. First detection of tilapia lake virus (TiLV) in wild river carp (Barbonymus schwanenfeldii) at Timah Tasoh Lake, Malaysia. J. Fish. Dis. 2018, 41, 1459-1462. [CrossRef]

19. Pradhan, P.K.; Paria, A.; Yadav, M.K.; Verma, D.K.; Gupta, S.; Swaminathan, T.R.; Rathore, G.; Sood, N.; Lal, K.K. Susceptibility of Indian major carp Labeo rohita to tilapia lake virus. Aquaculture 2020, 515, 734567. [CrossRef]

20. FAO. The State of World Fisheries and Aquaculture 2020; FAO: Rome, Italy, 2020; Available online: http:/ /www.fao.org/documents / card/en/c/ca9229en/ (accessed on 21 February 2021).

21. FAO. Oreochromis Mossambicus (Peters, 1852). 2021. Available online: http://www.fao.org/fishery/species/2408/en (accessed on 21 February 2021).

22. Philippart, J.C.; Ruwet, J.C. Ecology and distribution of tilapias. In The Biology and Culture of Tilapias, In Proceedings of the ICLARM Conference of the ICLARM-International Center for Living Aquatic Resources Management, Manila, Philippines, 2-5 September 1980; ICLARM-International Center for Living Aquatic Resources Management: Manila, Philippines, 1982; pp. 15-59.

23. Popma, T.J.; Lovshin, L.L. Worldwide Prospects for Commercial Production of Tilapia; Research and Development Series No. 41; Department of Fisheries and Allied Aquacultures Auburn University: Auburn, AL, USA, 1996; p. 23.

24. Costa-Pierce, B.; Riedel, R. Fisheries ecology of the tilapias in the subtropical lakes of the United States. Tilapia Aquaculture in the Americas. J. Word. Aquac. Soc. 2000, 2, 1-20.

25. Trewavas, E.; British, M. Tilapiine Fishes of the Genera Sarotherodon, Oreochromis, and Danakilia; British Museum (Natural History): London, UK, 1983; Volume 1983.

26. Uchida, K.; Kaneko, T.; Miyazaki, H.; Hasegawa, S.; Hirano, T. Excellent salinity tolerance of Mozambique tilapia (Oreochromis mossambicus): Elevated chloride cell activity in the branchial and opercular epithelia of the fish adapted to concentrated seawater. Zool. Sci. 2000, 17, 149-160. [CrossRef]

27. García-Ulloa, M.; Villa, R.L.; Martínez, M. Growth and feed utilization of the tilapia hybrid Oreochromis Mossambicus $\times$ O. Niloticus cultured at different salinities under controlled laboratory conditions. J. World. Aquac. Soc. 2001, 32, 117-121. [CrossRef]

28. King, M.; Sardella, B. The effects of acclimation temperature, salinity, and behavior on the thermal tolerance of Mozambique tilapia (Oreochromis mossambicus). J. Exp. Zool. A. Ecol. Integr. Physiol. J. 2017, 327, 417-422. [CrossRef]

29. Moorman, B.P.; Lerner, D.T.; Grau, E.G.; Seale, A.P. The effects of acute salinity challenges on osmoregulation in Mozambique tilapia reared in a tidally changing salinity. J. Exp. Biol. 2015, 218, 731-739. [CrossRef] [PubMed]

30. Baba, E.; Acar, Ü.; Öntaş, C.; Kesbiç, O.D.; Yilmaz, S. Evaluation of Citrus limon peels essential oil on growth performance, immune response of Mozambique tilapia Oreochromis mossambicus challenged with Edwardsiella tarda. Aquaculture 2016, 465, 13-18. [CrossRef]

31. Simbine, L.; Viana da Silva, J.; Hilsdorf, A.W.S. The genetic diversity of wild Oreochromis mossambicus populations from the Mozambique southern watersheds as evaluated by microsatellites. J. Appl. Ichthyol. 2014, 30, 272-280. [CrossRef]

32. D'Amato, M.E.; Esterhuyse, M.M.; Van der Waal, B.C.W.; Brink, D.; Volckaert, F.A.M. Hybridization and phylogeography of the Mozambique tilapia Oreochromis mossambicus in southern Africa evidenced by mitochondrial and microsatellite DNA genotyping. Conserv. Genet. 2007, 8, 475-488. [CrossRef]

33. Deines, A.M.; Bbole, I.; Katongo, C.; Feder, J.L.; Lodge, D.M. Hybridisation between native Oreochromis species and introduced Nile tilapia O. niloticus in the Kafue River, Zambia. Afr. J. Aquat. Sci. 2014, 39, 23-34. [CrossRef]

34. Firmat, C.; Alibert, P.; Losseau, M.; Baroiller, J.F.; Schliewen, U.K. Successive invasion-mediated interspecific hybridizations and population structure in the endangered cichlid Oreochromis mossambicus. PLoS ONE 2013, 8, e63880. [CrossRef]

35. Zengeya, T.A.; Booth, A.J.; Bastos, A.D.S.; Chimimba, C.T. Trophic interrelationships between the exotic Nile tilapia, Oreochromis niloticus and indigenous tilapiine cichlids in a subtropical African river system (Limpopo River, South Africa). Environ. Biol. Fishes. 2011, 92, 479-489. [CrossRef]

36. Zengeya, T.A.; Robertson, M.P.; Booth, A.J.; Chimimba, C.T. Ecological niche modeling of the invasive potential of Nile tilapia Oreochromis niloticus in African river systems: Concerns and implications for the conservation of indigenous congenerics. Biol. Invasions 2013, 15, 1507-1521. [CrossRef]

37. Zengeya, T.A.; Robertson, M.P.; Booth, A.T.; Chimimba, C.T. A qualitative ecological risk assessment of the invasive Nile tilapia, Oreochromis niloticus in a sub-tropical African river system (Limpopo River, South Africa). Aquat. Conserv. Mar. Freshw. Ecosyst. 2013, 23, 51-64. [CrossRef] 
38. IUCN 2019. Oreochromis mossambicus (Errata Version Published in 2020), The IUCN Red List of Threatened Species 2019. 2019. Available online: https:/ / dx.doi.org/10.2305/IUCN.UK.2019-3.RLTS.T63338A174782954.en (accessed on 21 February 2021).

39. Nanthini, R.; Majeed, S.A.; Vimal, S.; Taju, G.; Sivakumar, S.; Kumer, S.S.; Pillai, D.; Sneha, K.G.; Rakesh, C.G.; Hameed, A.S.S. In vitro propagation of tilapia lake virus in cell lines developed from Oreochromis mossambicus. J. Fish Dis. 2019, 42, 1543-1552. [CrossRef] [PubMed]

40. Amal, M.N.A.; Koh, C.B.; Nurliyana, M.; Suhaiba, M.; Nor-Amalina, Z.; Santha, S.; Diyana-Nadhirah, K.P.; Yusof, M.T.; InaSalwany, M.Y.; Zamri-Saad, M.; et al. A case of natural co-infection of Tilapia Lake Virus and Aeromonas veronii in a Malaysian red hybrid tilapia (Oreochromis niloticus $\times$ O. mossambicus) farm experiencing high mortality. Aquaculture 2018, 485, 12-16. [CrossRef]

41. Tattiyapong, P.; Sirikanchana, K.; Surachetpong, W. Development and validation of a reverse transcription quantitative polymerase chain reaction for tilapia lake virus detection in clinical samples and experimentally challenged fish. J. Fish Dis. 2018, 41, 255-261. [CrossRef] [PubMed]

42. Tattiyapong, P.; Dachavichitlead, W.; Surachetpong, W. Experimental infection of Tilapia Lake Virus (TiLV) in Nile tilapia (Oreochromis niloticus) and red tilapia (Oreochromis spp.). Vet. Microbiol. 2017, 207, 170-177. [CrossRef]

43. Iwamoto, T.; Nakai, T.; Arimoto, M.; Furesawa, I. Cloning of the fish cell line SSN-1 for piscine nodaviruses. Dis. Aquatic. Organ. 2000, 43, 81-89. [CrossRef]

44. Reed, L.J.; Muench, H. A simple method of estimating fifty per cent endpoints. Am. J. Epidemiol. 1938, 27, 493-497. [CrossRef]

45. Nicholson, P.; Rawiwan, P.; Surachetpong, W. Detection of Tilapia Lake Virus Using Conventional RT-PCR and SYBR Green RT-qPCR. J. Vis. Exp. 2018, 141, e58596. [CrossRef] [PubMed]

46. Yamkasem, J.; Piewbang, C.; Techangamsuwan, S.; Pierezan, F.; Soto, E.; Surachetpong, W. Susceptibility of ornamental African cichlids Aulonocara spp. to experimental infection with Tilapia lake virus. Aquaculture 2021, 542, 736920. [CrossRef]

47. Piewbang, C.; Jo, W.K.; Puff, C.; Ludlow, M.; van der Vries, E.; Banlunara, W.; Rungsipipat, A.; Kruppa, J.; Jung, K.; Techangamsuwan, S. Canine Bocavirus Type 2 Infection Associated with Intestinal Lesions. Vet. Pathol. 2018, 55, 434-441. [CrossRef]

48. FAO. Tilapia Lake Virus Expert Knowledge Elicitation Risk Assessment (December 2018). In FAO Animal Health Risk Analysis Assessment; FAO: Rome, Italy, 2018; Available online: http:/ /www.fao.org/3/CA2864EN/ca2864en.pdf (accessed on 2 April 2021).

49. OIE. Infection with Tilapia Lake Virus (TiLV)-A Novel Orthomyxo-Like Virus. Available online: www.oie.int/fileadmin/Home/ eng/Internationa_Standard_Setting/docs/pdf/Aquatic_Commission/A_TiLV_disease_card.pdf (accessed on 2 April 2021).

50. Liamnimitr, P.; Thammatorn, W.; U-thoomporn, S.; Tattiyapong, P.; Surachetpong, W. Non-lethal sampling for Tilapia Lake Virus detection by RT-qPCR and cell culture. Aquaculture 2018, 486, 75-80. [CrossRef]

51. Thammatorn, W.; Rawiwan, P.; Surachetpong, W. Minimal risk of tilapia lake virus transmission via frozen tilapia fillets. J. Fish Dis. 2019, 42, 3-9. [CrossRef]

52. Rakus, K.; Mojzesz, M.; Widziolek, M.; Pooranachandran, N.; Teitge, F.; Surachetpong, W.; Chadzinska, M.; Steinhagen, D.; Adamek, M. Antiviral response of adult zebrafish (Danio rerio) during tilapia lake virus (TiLV) infection. Fish Shellfish Immunol. 2020, 101, 1-8. [CrossRef]

53. OIE. Tilapia Lake Virus Disease, Malaysia. Immediate Notification. Available online: https://www.oie.int/wahis_2/public/ wahid.php/Reviewreport/Review?page_refer=MapFullEventReport\&reportid=24809 (accessed on 5 April 2021).

54. Pierezan, F.; Yun, S.; Piewbang, C.; Surachetpong, S.; Soto, E. Pathogenesis and immune response of Nile tilapia (Oreochromis niloticus) exposed to Tilapia lake virus by intragastric route. Fish Shellfish Immunol. 2020, 107, 289-300. [CrossRef]

55. Pulido, L.L.H.; Mora, C.M.; Hung, A.L.; Dong, H.T.; Senapin, S. Tilapia lake virus (TiLV) from Peru is genetically close to the Israeli isolates. Aquaculture 2019, 510, 61-65. [CrossRef]

56. He, A.; Luo, Y.; Liu, L.; Li, S.; Wang, C. Complete mitochondrial DNA sequences of the Nile tilapia (Oreochromis niloticus) and Blue tilapia (Oreochromis aureus): Genome characterization and phylogeny applications. Mol. Biol. Rep. 2011, 38, $2015-2021$. [CrossRef] [PubMed]

57. Xia, J.; Wan, Z.; Ng, Z.; Wang, L.; Fu, G.; Lin, G.; Liu, F.; Yue, G. Genome-wide discovery and in silico mapping of gene-associated SNPs in Nile tilapia. Aquaculture 2014, 432, 67-73. [CrossRef]

58. Dinesh, K.R.; Lim, T.M.; Chan, W.K.; Phang, V.P.E. Genetic variation inferred from RAPD fingerprinting in three species of tilapia. Aquac. Int. 1996, 4, 19-20. [CrossRef]

59. Skliris, G.; Richards, R. Nodavirus isolated from experimentally infected tilapia, Oreochromis mossambicus (Peters). J. Fish Dis. 2002, 22, 315-318. [CrossRef]

60. Abraham, T.J.; Namdeo, A.S.; Adikesavalu, H.; Banerjee, S. Pathogenicity and pathology of Straptococcus agalactiae in challenged Mozambique tilapia Oreochromis mossambicus (Peters 1852) juveniles. Aquat. Res. 2019, 2, 182-190. [CrossRef]

61. Ndong, D.; Chen, Y.Y.; Lin, Y.H.; Vaseeharan, B.; Chen, J.C. The immune response of tilapia Oreochromis mossambicus and its susceptibility to Streptococcus iniae under stress in low and high temperatures. Fish Shellfish Immunol. 2007, 22, 686-694. [CrossRef] [PubMed] 